\title{
Genetic control of the rate of transmission of rye B chromosomes. III. Male meiosis and gametogenesis
}

\author{
M. MAR JIMÉNEZ, FÉLIX ROMERA, MÓNICA GONZÁLEZ-SÁNCHEZ \& \\ MARÍA J. PUERTAS* \\ Departamento de Genética, Facultad de Biología, Universidad Complutense, 28040 Madrid, Spain
}

\begin{abstract}
Male meiosis and gametogenesis were studied at metaphase I, metaphase and anaphase of the first pollen grain mitosis, and bicellular and tricellular pollen grain stages in 2B rye plants belonging to the low $(\mathrm{L})$ and high $(\mathrm{H}) \mathrm{B}$ transmission rate lines previously selected. Our results show that B chromosome behaviour significantly differs in both lines whereas the behaviour of the normal complement does not differ. In the L line the Bs form univalents in 81.07 per cent of the metaphase I cells, and are conserved in 44.14 per cent of the pollen grains at first metaphase whereas the remaining Bs are eliminated as micronuclei. In the $\mathrm{H}$ line the $\mathrm{Bs}$ form bivalents in 87.71 per cent of the metaphase I cells, and are present in 82.48 per cent of pollen grains at first metaphase. The $\mathrm{Bs}$ of the $\mathrm{L}$ and $\mathrm{H}$ lines do not differ in their ability to undergo nondisjunction at first pollen grain anaphase. This indicates that the different $\mathrm{B}$ transmission in the $\mathrm{L}$ and $\mathrm{H}$ lines results from their differential ability to form uni- or bivalents at metaphase I, which determines their loss or conservation in the pollen grains. The $\mathrm{L}$ and $\mathrm{H}$ lines also differ in pollen viability at the tricellular stage because 19.75 per cent of pollen grains of the $\mathrm{L}$ line and only 1.2 per cent of the $\mathrm{H}$ line are inviable.
\end{abstract}

Keywords: B chromosomes, B transmission control, meiosis, microgametogenesis, pollen mitosis, Secale cereale.

\section{Introduction}

The transmission of rye $\mathrm{B}$ chromosomes (Bs) is non-Mendelian because of the mechanism of $\mathrm{B}$ accumulation and of the variable behaviour of the Bs during meiosis and gametogenesis (Jones \& Puertas (1993) for a review). The mechanism of accumulation consists of nondisjunction at the first division of the female and male gametophytes, and preferential segregation to the nucleus which will form the gametes.

In previous papers we reported a high variation in B transmission rate (Puertas et al., 1990) and selection gain for the character mean number of Bs per plant in the progeny in $+2 \mathrm{~B} \times 0$ t $0 \mathrm{~B}$ and $q 0 \mathrm{~B} \times \frac{2}{2} \mathrm{~B}$ crosses (Romera et al., 1991; Jiménez et al., 1995) demonstrating the existence of genotypes which affect this character that we called low (L) and high (H) B transmission rate lines.

Rye Bs are stable during sporophyte development.

\footnotetext{
*Correspondence. E-mail: majetas@eucmax.sim.ucm.es
}

The same number of Bs is observed in the root tips and at metaphase I of meiosis, whereas at meiosis and pollen mitosis B behaviour is variable (Kishikawa, 1965; Puertas et al., 1979; Santos et al., 1993). This indicates that the variation in $\mathrm{B}$ transmission must be caused, at least partially, by the variation in $\mathrm{B}$ behaviour during meiosis and gametogenesis. In the present work we show the results of the quantitative analysis of some relevant stages of microsporogenesis and microgametogenesis in $2 \mathrm{~B}$ plants of the $\mathrm{L}$ and $\mathrm{H}$ lines. A quantitative analysis of rye $\mathrm{B}$ behaviour during megasporogenesis and megagametogenesis would be much more difficult and has not been attempted.

\section{Material and methods}

The material used was Secale cereale $(2 n=14+\mathrm{Bs})$ from the Puyo population in which about 60 per cent of the plants naturally carry Bs.

The plants studied in this work belong to the third generation of selection to obtain low (L) and high 
(H) B transmission rate lines (see Jiménez et al., 1995 for a description of the selection method).

The chromosome number of seeds belonging to the $\mathrm{L}$ and $\mathrm{H}$ lines was first counted in root tips following fixation in $1: 3$ acetic acid:ethanol and stained by the Feulgen method. 2B descendants of five $q 2 \mathrm{~B} \times \mathrm{O}^{*} \mathrm{OB}$ crosses of the $\mathrm{L}$ line and seven of the $\mathrm{H}$ line were studied. Sibling plants are named with the same letter in the tables of the present work. For example, La2, La4, La9 and La 10 are siblings of the $a$ cross.

The plants were grown in our experimental field and their anthers were excised at various developmental stages: metaphase I, first pollen mitosis, bicellular and tricellular pollen. They were similarly fixed in $1: 3$ acetic acid:ethanol. When possible, anthers at different developmental stages were taken from different heads of the same plant. Anthers in meiosis and first pollen mitosis were stained by the Feulgen method, whereas bi- and tricellular pollen grains were stained with 1 per cent aceto-carmine to score micronuclei in bicellular pollen and pollen viability in tricellular mature grains. Inviable pollen is easily observed because it is empty of starch granules and often shows irregular shape and/or abnormal size.

The STATGRAPHICS computer program version 7.0 was used for the statistical analyses.

\section{Results}

\section{Meiosis}

The Bs of $2 \mathrm{~B}$ plants form two univalents or one rod bivalent bound by the long arm in most metaphase I cells. Ring bivalents or rod bivalents bound by the short arm are rarely observed and are not differentiated in the analyses of the present work.

Tables 1 and 2 show the behaviour of the normal complement (As) and the Bs at metaphase I in eight plants of the $\mathrm{L}$ line and five of the $\mathrm{H}$ line, respectively. The data are expressed in terms of bound arms per pollen mother cell. The cells are divided into two classes: those having 7A bivalents and 2B univalents and those having $7 \mathrm{~A}$ bivalents and $1 \mathrm{~B}$ bivalent. The As never form univalents. B association in the $\mathrm{L}$ and $\mathrm{H}$ lines was compared using a $\chi^{2}$ contingency test which was highly significant $(P<0.0001$, Table 3$)$. In the $\mathrm{L}$ line 257 cells out of 317 (81.07 per cent) show 2B univalents, whereas in the $\mathrm{H}$ line only 22 out of 179 cells (12.29 per cent) show univalents.

Mean bound arms per cell in the As were compared by a two-way ANova (Table 4) where the

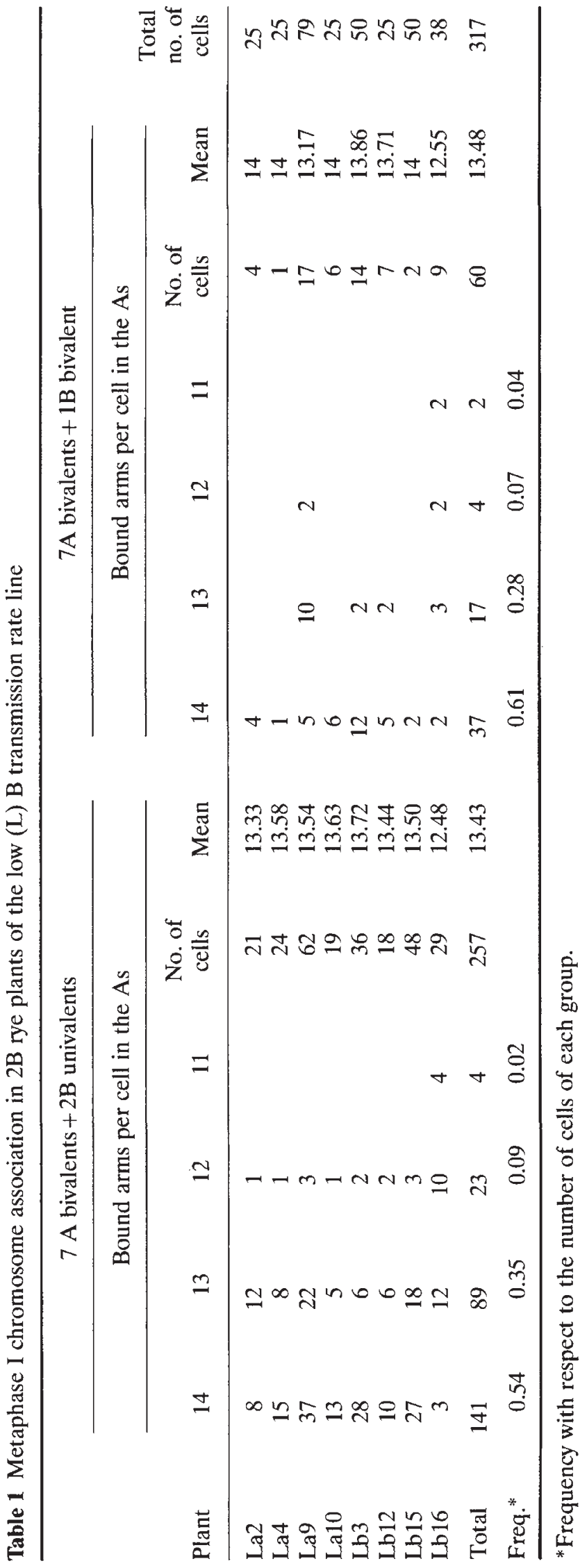




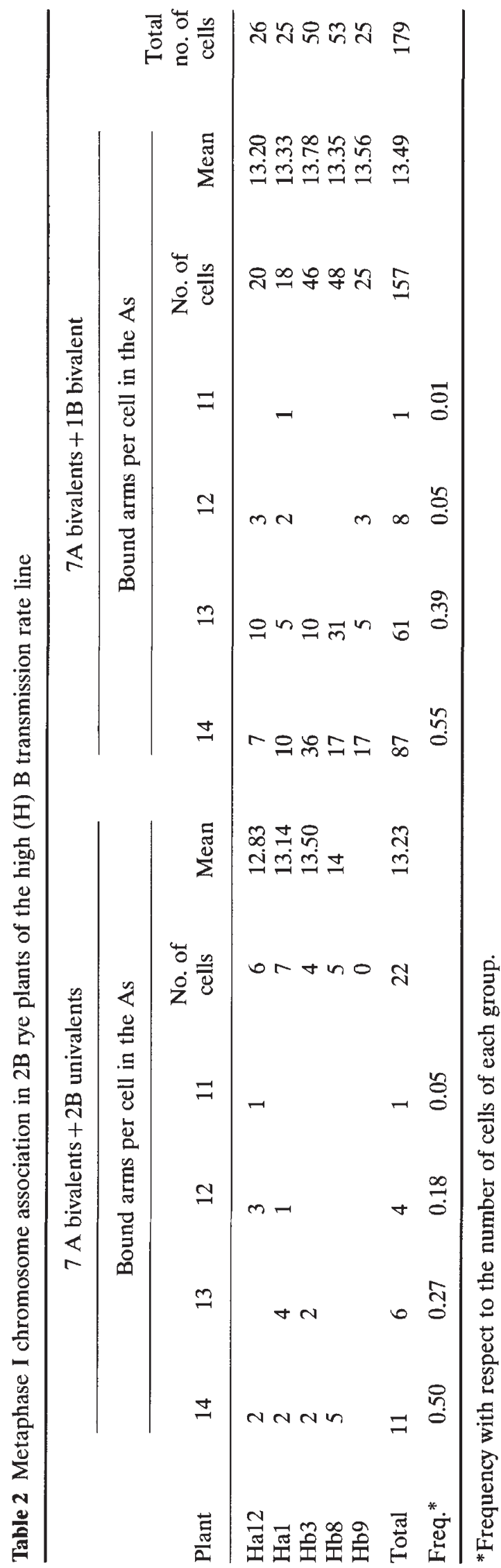

Table 3 Contingency test for the number of metaphase I cells showing $2 \mathrm{~B}$ univalents or $1 \mathrm{~B}$ bivalent in the $\mathrm{H}$ and $\mathrm{L}$. lines of rye

\begin{tabular}{llcc}
\hline Line & & 2 B univ. & 1 B biv. \\
\hline L & Obs. & 257 & 60 \\
& Exp. & 178.31 & 138.69 \\
H & Obs. & 22 & 157 \\
& Exp. & 100.69 & 78.31 \\
\hline \multirow{2}{*}{$\chi_{1}^{2}=220.55, P<0.0001}$. & &
\end{tabular}

sources of variation are the line $(\mathrm{L}$ or $\mathrm{H})$ and $B$ associations (univalents or bivalents). None of these variables or the interaction was found to have a significant effect indicating that the As behave similarly in the $\mathrm{H}$ and $\mathrm{L}$ lines and irrespective of $\mathrm{B}$ association.

\section{First pollen grain metaphase}

The chromosome constitution of first pollen grain metaphase shows the final result of chromosome behaviour at meiosis. If the $\mathrm{B}$ had a Mendelian behaviour $7 \mathrm{As}+1 \mathrm{~B}$ would be observed at this stage in the 2B plants; however, we found different cell types shown in Tables 5 and 6 for the $\mathrm{L}$ and $\mathrm{H}$ lines, respectively. In these tables the cells have been grouped into those showing $\mathrm{B}$ loss and those showing $\mathrm{B}$ conservation. Metaphases of the first group come from meiotic anaphases where the Bs underwent an unequal distribution (2-0) or lagged and were not included in the telophasic nuclei, being eliminated or remaining as micronuclei in the pollen grain.

In the group of pollen grains showing the Bs, $7 \mathrm{As}+1 \mathrm{~B}$ are the most common metaphases in both lines, although a small percentage of $7 \mathrm{As}+2 \mathrm{Bs}$ and $7 \mathrm{As}+1 \mathrm{~B}+1$ micronucleus is also present. These last two cases indicate that the $2 \mathrm{Bs}$ have migrated to the same pole at meiosis but in the latter case only one $B$ reached the telophasic nucleus.

Tables 5 and 6 also show that cell types are the same in the $\mathrm{L}$ and $\mathrm{H}$ lines, but their frequencies are different. In the $\mathrm{L}$ line 262 out of 469 pollen grains show B loss (55.86 per cent), and the Mendelian expectation (7As $+1 \mathrm{~B})$ is observed in 38.16 per cent of the cases. In the $\mathrm{H}$ line 119 out of 936 pollen grains show B loss (12.71 per cent), and the Mendelian expectation is observed in 82.48 per cent of the cases. The difference in $\mathrm{B}$ loss or $\mathrm{B}$ conservation between the lines was compared by a $\chi^{2}$ contingency test, which was highly significant $(P<0.0001$, Table 7).

(C) The Genetical Society of Great Britain, Heredity, 78, 636-644. 
Table 4 Analysis of variance for the mean bound arms per cell at metaphase $\mathrm{I}$ in the $\mathrm{L}$ and $\mathrm{H}$ lines of rye

\begin{tabular}{lccrr}
\hline Source of variation & Sum of squares & d.f. & Mean square & $F$-ratio \\
\hline Main effects & & & & 0.0909 \\
$\quad$ A: Line & 0.0909 & 1 & 0.1605 & 0.476 \\
$\quad$ B: B Pairing & 0.1605 & 1 & 0.0474 & 0.840 \\
Interactions & 0.0474 & 1 & 0.1911 & 0.248 \\
$\quad$ AB & 4.0132 & 21 & 0.6287 \\
Residual & 4.3796 & 24 & & \\
Total (corrected) & & & \\
\hline
\end{tabular}

Table 5 First pollen grain metaphase in $2 \mathrm{~B}$ rye plants of the $\mathrm{L}$ line $(\mathrm{mn}=$ micronucleus $)$

\begin{tabular}{|c|c|c|c|c|c|c|c|c|c|}
\hline \multirow[b]{2}{*}{ Plant } & \multicolumn{4}{|c|}{ B chromosome loss } & \multicolumn{4}{|c|}{ B chromosome conservation } & \multirow{2}{*}{$\begin{array}{c}\text { Total no } \\
\text { of cells }\end{array}$} \\
\hline & 7As & $7+1 \mathrm{mn}$ & $7+2 \mathrm{mn}$ & Cells scored & $7+1 \mathrm{~B}$ & $7+2 B$ & $7+1 B+1 m n$ & Cells scored & \\
\hline $\mathrm{La} 2$ & 10 & 15 & & 25 & 3 & & 1 & 4 & 29 \\
\hline $\mathrm{La} 4$ & 11 & 34 & 3 & 48 & 17 & 4 & 2 & 23 & 71 \\
\hline La9 & 8 & 17 & 1 & 26 & 26 & 1 & 2 & 29 & 55 \\
\hline Lb8 & 7 & & & 7 & 31 & 4 & & 35 & 42 \\
\hline Lb12 & 11 & 29 & & 40 & 28 & & & 28 & 68 \\
\hline Lb16 & 4 & 6 & & 10 & 9 & 1 & & 10 & 20 \\
\hline Total & 88 & 165 & 9 & 262 & 179 & 15 & 13 & 207 & 469 \\
\hline Freq. & 0.19 & 0.35 & 0.02 & $(0.5586)$ & 0.38 & 0.03 & 0.03 & $(0.4414)$ & \\
\hline
\end{tabular}

Table 6 First pollen grain metaphase in 2B rye plants of the $\mathrm{H}$ line $(\mathrm{mn}=$ micronucleus)

\begin{tabular}{|c|c|c|c|c|c|c|c|c|c|}
\hline \multirow[b]{2}{*}{ Plant } & \multicolumn{4}{|c|}{ B chromosome loss } & \multicolumn{4}{|c|}{ B chromosome conservation } & \multirow{2}{*}{$\begin{array}{l}\text { Total no. } \\
\text { of cells }\end{array}$} \\
\hline & 7As & $7+1 \mathrm{mn}$ & $7+2 m n$ & Cells scored & $7+1 \mathrm{~B}$ & $7+2 B$ & $7+1 B+1 m n$ & Cells scored & \\
\hline Ha12 & 2 & & & 2 & 43 & 2 & 1 & 46 & 48 \\
\hline Ha16 & 1 & 12 & & 13 & 15 & 3 & 1 & 19 & 32 \\
\hline Ha19 & 26 & 1 & & 27 & 96 & 4 & 3 & 103 & 130 \\
\hline $\mathrm{Ha} 20$ & 13 & 1 & & 14 & 119 & 5 & 2 & 126 & 140 \\
\hline $\mathrm{Ha} 21$ & 18 & 3 & 2 & 23 & 92 & 6 & 1 & 99 & 122 \\
\hline $\mathrm{Ha} 22$ & 6 & 3 & & 9 & 122 & 7 & 2 & 131 & 140 \\
\hline $\mathrm{Ha} 23$ & 18 & 2 & & 20 & 114 & 4 & 2 & 120 & 140 \\
\hline $\mathrm{Hb} 1$ & 1 & 4 & 1 & 6 & 38 & 1 & & 39 & 45 \\
\hline $\mathrm{Hb} 3$ & 1 & & & 1 & 24 & & & 24 & 25 \\
\hline $\mathrm{Hb} 8$ & & & & 0 & 36 & & & 36 & 36 \\
\hline $\mathrm{Hb} 9$ & 4 & & & 4 & 73 & 1 & & 74 & 78 \\
\hline Total & 90 & 26 & 3 & 119 & 772 & 33 & 12 & 817 & 936 \\
\hline Freq. & 0.096 & 0.028 & 0.003 & $(0.1271)$ & 0.825 & 0.035 & 0.013 & $(0.8729)$ & \\
\hline
\end{tabular}

It is interesting to compare the results of metaphase I of meiosis with those of first pollen grain metaphase to estimate the relationship between $B$ univalent or bivalent formation with their loss or conservation. In the $\mathrm{L}$ line the $\mathrm{Bs}$ formed bivalents in 18.93 per cent and univalents in 81.07 per cent of the cells (Table 1); because a total of 469 pollen grain metaphases were observed (Table 5), 
Table 7 Contingency test for B chromosome loss or conservation at first pollen grain metaphase in the $\mathrm{H}$ and $\mathrm{L}$ lines of rye

\begin{tabular}{llll}
\hline Line & & B loss & B conservation \\
\hline L & Obs. & 262 & 207 \\
& Exp. & 127.18 & 341.82 \\
H & Obs. & 119 & 817 \\
& Exp. & 253.82 & 682.18 \\
\hline
\end{tabular}

$\chi_{1}^{2}=906.11, P<0.0001$.

$469 \times 0.1893=88.92$ pollen grains are expected to conserve the $\mathrm{B}$ at pollen metaphase if all Bs forming bivalents segregated normally in both meiotic anaphases; however, 207 were observed (Table 5). Therefore, $207-88.92=118.08$ pollen metaphases conserving the B come from metaphase I cells with 2B univalents. $118.08 /(469 \times 0.8107)=0.3105$ is the frequency of metaphase I cells with $2 \mathrm{~B}$ univalents which gave rise to pollen metaphases with the $\mathrm{B}$, whereas in the remaining cells with $2 \mathrm{~B}$ univalents $(0.8107-0.3105=0.5002)$ the Bs are lost from metaphase I to first pollen mitosis.

In the $\mathrm{H}$ line the Bs formed bivalents in 87.71 per cent and univalents in 12.29 per cent of the cells (Table 2). Because 936 pollen grain metaphases were observed (Table 6), $936 \times 0.8771=820.96$ pollen grains are expected to conserve the $\mathrm{B}$, and 817 were observed. This coincidence is not surprising because if we assume that the same proportion of $\mathrm{B}$ univalents was conserved in the $\mathrm{L}$ and $\mathrm{H}$ lines ( 31.05 per cent), only $0.1229 \times 0.3105=0.038$ of the univalents would be conserved in the pollen grains. This small proportion is undetectable.

\section{First pollen grain anaphase}

The results of first pollen grain anaphase are shown in Tables 8 and 9 for the $\mathrm{L}$ and $\mathrm{H}$ lines, respectively. The frequency of pollen grains without Bs is the same in metaphase and anaphase (about 60 per cent in the $\mathrm{L}$ line and 10 per cent in the $\mathrm{H}$ line). The frequency of cells with micronuclei is also the same (about 40 per cent in the $\mathrm{L}$ line and 4 per cent in the $\mathrm{H}$ line) indicating that the $\mathrm{Bs}$ are not lost from metaphase to anaphase of the first pollen mitosis.

It is interesting to compare $\mathrm{B}$ nondisjunction at the first pollen grain mitosis with the $7 \mathrm{~A}+$ $1 \mathrm{~B} / 7 \mathrm{~A}+1 \mathrm{~B}$ migration, to see if the $\mathrm{H}$ and $\mathrm{L}$ lines differ in this important feature (Table 10). In this case we cannot calculate the $\chi^{2}$ because the number of cells showing normal disjunction of the Bs is very low, but the coincidence between observed and expected results allows us to assume that the difference is nonsignificant. It is also remarkable that in both lines the frequency of Bs undergoing nondisjunction at pollen anaphase coincides with the frequency of Bs present at pollen metaphase (Tables $5,6,8$ and 9 ). These results indicate that the low or high $\mathrm{B}$ transmission rate in the $\mathrm{L}$ and $\mathrm{H}$ lines is not related to a differential nondisjunction ability.

\section{Bicellular and tricellular pollen grains}

An increase of the number of pollen grains with micronuclei at the bicellular pollen stage with respect to first grain metaphase would indicate that some Bs might be lost after nondisjunction. However, the observed frequency decreased from 39.87 per cent (Table 5) to 9.8 per cent (Table 11) in the $\mathrm{L}$ line and from 4.38 per cent (Table 6) to

Table 8 First pollen grain anaphase in $2 \mathrm{~B}$ plants of the $\mathrm{L}$ line of rye $(\mathrm{mn}=$ micronucleus; $\mathrm{ndj}=$ nondisjunction $)$

\begin{tabular}{|c|c|c|c|c|c|c|c|c|c|}
\hline \multirow[b]{2}{*}{ Plant } & \multicolumn{3}{|c|}{ B chromosome loss } & \multicolumn{5}{|c|}{ B chromosome conservation } & \multirow{2}{*}{$\begin{array}{l}\text { Total no. } \\
\text { of pollen } \\
\text { grains }\end{array}$} \\
\hline & $7-7$ & $7-7+1 \mathrm{mn}$ & Pollen scored & 1B ndj & 2B ndj & $8-8$ & $1 \mathrm{ndj}+1 \mathrm{mn}$ & Pollen scored & \\
\hline $\mathrm{La} 2$ & & 2 & 2 & 3 & & & 1 & 4 & 6 \\
\hline La4 & 2 & 9 & 11 & 4 & & & & 4 & 15 \\
\hline La9 & 3 & 9 & 12 & 10 & & & 1 & 11 & 23 \\
\hline La11 & 10 & 14 & 24 & 5 & & 1 & & 6 & 30 \\
\hline Lb3 & 8 & 17 & 25 & 6 & 1 & 1 & & 8 & 33 \\
\hline Lb8 & 3 & 1 & 4 & 11 & & 1 & 1 & 13 & 17 \\
\hline Lb12 & 3 & 4 & 7 & 2 & & & & 2 & 9 \\
\hline Lb16 & 1 & 1 & 2 & 5 & & & & 5 & 7 \\
\hline Total & 30 & 57 & 87 & 46 & 1 & 3 & 3 & 53 & 140 \\
\hline Freq. & 0.214 & 0.407 & $(0.6214)$ & 0.329 & 0.007 & 0.021 & 0.021 & $(0.3786)$ & \\
\hline
\end{tabular}


Table 9 First pollen grain anaphase in $2 \mathrm{~B}$ plants of the $\mathrm{H}$ line of rye $(\mathrm{mn}=$ micronucleus; $\mathrm{ndj}=$ nondisjunction $)$

\begin{tabular}{|c|c|c|c|c|c|c|c|c|}
\hline \multirow[b]{2}{*}{ Plant } & \multicolumn{3}{|c|}{ B chromosome loss } & \multicolumn{4}{|c|}{ B chromosome conservation } & \multirow{2}{*}{$\begin{array}{l}\text { Total no } \\
\text { of pollen } \\
\text { grains }\end{array}$} \\
\hline & $7-7$ & $7-7+1 m n$ & Pollen scored & 1B ndj & 2B ndj & $8-8$ & Pollen scored & \\
\hline Ha16 & & 2 & 2 & 1 & 1 & & 2 & 4 \\
\hline Ha19 & 1 & 2 & 3 & 12 & & 1 & 13 & 16 \\
\hline $\mathrm{Ha} 20$ & 1 & 1 & 2 & 16 & & 1 & 17 & 19 \\
\hline $\mathrm{Ha} 21$ & & & 0 & 13 & & & 13 & 13 \\
\hline Ha22 & 1 & & 1 & 8 & & 2 & 10 & 11 \\
\hline $\mathrm{Ha} 23$ & 1 & & 1 & 8 & & & 8 & 9 \\
\hline Hb1 & & 1 & 1 & 8 & & & 8 & 9 \\
\hline $\mathrm{Hb} 3$ & & & 0 & 4 & & 1 & 5 & 5 \\
\hline $\mathrm{Hb} 8$ & & & 0 & 10 & & & 10 & 10 \\
\hline Hb9 & & & 0 & 25 & & & 25 & 25 \\
\hline $\mathrm{Hb} 12$ & 1 & & 1 & 14 & & & 14 & 15 \\
\hline Total & 5 & 6 & 11 & 119 & 1 & 5 & 125 & 136 \\
\hline Freq. & 0.037 & 0.044 & $(0.0809)$ & 0.875 & 0.007 & 0.037 & $(0.9191)$ & \\
\hline
\end{tabular}

Table 10 Contingency table for B chromosome nondisjunction (ndj) vs. $7+1 / 7+1$ migration at first pollen grain anaphase in the $\mathrm{H}$ and $\mathrm{L}$ lines of rye

\begin{tabular}{llcl}
\hline Line & & $7-7+$ B ndj & $8-8$ migration \\
\hline L & Obs. & 50 & 3 \\
& Exp. & 50.62 & 2.38 \\
$\mathrm{H}$ & Obs. & 120 & 5 \\
& Exp. & 119.38 & 5.62 \\
\hline
\end{tabular}

1.62 per cent (Table 11 ) in the $\mathrm{H}$ line. The difference is probably caused by the degradation of micronuclei during pollen maturation.

We observed tricellular pollen grains to score the number of viable pollen grains. Interestingly, in the $\mathbf{L}$ line the frequency of inviable pollen grains is high, reaching up to 49.85 per cent in one plant. In the $\mathrm{H}$ line the percentage of inviable pollen is low $(1.21$ per cent). This strongly suggests that when the behaviour of the $\mathrm{B}$ is regular ( $\mathrm{H}$ line) pollen development is not affected. However, the irregular behaviour of the $\mathrm{Bs}$ in the $\mathrm{L}$ line may affect pollen viability in a high percentage of cases.

Unfortunately, it is not possible to observe micronuclei in tricellular pollen grains because of the high starch granule content. Figure 1 summarizes the most relevant results of this work.

\section{Discussion}

Pollen mitosis and especially meiosis of rye plants with Bs have been previously studied. All works report a large variation of $\mathrm{B}$ chromosome behaviour (Jones \& Puertas, 1993; Jones, 1995 for a review). The novelty of the present work is that we identify genetically controlled sources of variation because the differential behaviour is found in plants selected for high or low B transmission to the progeny.

It can be deduced from our results that the main cause accounting for the differential $\mathrm{B}$ transmission in the $\mathrm{L}$ and $\mathrm{H}$ lines is the ability to form $\mathrm{B}$ bivalents at metaphase I. When the Bs form bivalents they are conserved in the pollen grains whereas when the Bs form univalents they are conserved only in about 20 per cent of the cases, and the remaining Bs are eliminated as micronuclei which decrease in frequency during pollen maturation. In all probability the micronuclei are degraded together with plastid and mitochondrial DNA modification/ degradation occurring during pollen maturation. This phenomenon is a common occurrence among plants exhibiting maternal cytoplasmic inheritance. There is evidence that organelle nucleoids disappear from the generative or sperm cells by the time of pollen maturity in nine species, including Triticum, representing both bicellular and tricellular pollen types (Mogensen, 1996).

Matthews \& Jones (1982, 1983) developed a computer simulation model to identify the parameters which were considered to represent the main processes determining the transmission rates and distribution characteristics of rye $\mathrm{B}$. The model identified that variation in both 'nonpairing' and 'nonpaired' loss rate can provide a means for regulating the final mean equilibrium B-level per plant 
Table 11 Pollen grains showing micronuclei at bicellular pollen stage and pollen viability at tricellular pollen stage in the $\mathrm{L}$ and $\mathrm{H}$ lines of rye

\begin{tabular}{|c|c|c|c|c|c|}
\hline \multirow[b]{2}{*}{ Plant } & \multicolumn{3}{|c|}{ Bicellular pollen } & \multicolumn{2}{|c|}{ Tricellular pollen } \\
\hline & $\begin{array}{l}\text { Pollen } \\
\text { with } \\
1 \mathrm{mn}\end{array}$ & $\begin{array}{l}\text { Pollen } \\
\text { with } \\
2 \mathrm{mn}\end{array}$ & $\begin{array}{l}\text { No. of } \\
\text { pollen grains } \\
\text { scored }\end{array}$ & $\begin{array}{c}\% \text { of } \\
\text { inviable } \\
\text { pollen }\end{array}$ & $\begin{array}{l}\text { No. of } \\
\text { pollen grains } \\
\text { scored }\end{array}$ \\
\hline Lc3 & 10 & & 150 & 13.33 & 300 \\
\hline Ld1 & 13 & & 250 & 13.74 & 600 \\
\hline Ld7 & 15 & & 150 & 11.66 & 300 \\
\hline Ld16 & 21 & 1 & 300 & 14.00 & 600 \\
\hline Le7 & 37 & 1 & 150 & 13.72 & 600 \\
\hline Lc8 & & & - & 49.85 & 300 \\
\hline Ld6 & & & - & 22.00 & 300 \\
\hline Total & 96 & 2 & 1000 & 19.75 & 3000 \\
\hline $\mathrm{Hc} 1$ & 0 & & 150 & 0.33 & 300 \\
\hline Hd15 & 0 & & 150 & 0.33 & 300 \\
\hline He16 & 4 & & 150 & 1.16 & 600 \\
\hline Hf12 & 10 & & 300 & 0.67 & 300 \\
\hline Hf 24 & 3 & & 150 & 0.33 & 300 \\
\hline Hg6 & 0 & & 150 & 2.33 & 300 \\
\hline Hf 9 & & & - & 2.33 & 300 \\
\hline Hf9 & & & - & 2.33 & 300 \\
\hline Total & 17 & & 1050 & 1.21 & 2400 \\
\hline
\end{tabular}

and the number of generations taken for the equilibrium levels to be attained. Adjustment of equilibrium levels is effectively brought about by variation in the nonpairing rate parameter and the nonpaired loss rate parameter rather than through fluctuations in directed nondisjunction. As a matter of fact, the rate of directed nondisjunction is consistently high in all varieties studied to date. These authors also indicated that varietal differences in the nonpairing rate and the nonpaired loss rate suggest genetically controlled sources of variation either between the Bs of different strains or else in the interactions between the $\mathrm{Bs}$ and their respective $\mathrm{A}$ chromosome complements.

Our results coincide with their model because we find that the main cause for the differential transmission of $\mathrm{B}$ chromosomes in the $\mathrm{H}$ and $\mathrm{L}$ lines is the loss or conservation of the $\mathrm{B}$ in the pollen grains which is determined by $\mathrm{B}$ association at metaphase I, whereas the nondisjunction process is not modified.

In our previous studies on the selection of the $\mathrm{L}$ and $\mathrm{H}$ lines (Romera et al., 1991; Jiménez et al., 1995) we deduced that the different B transmission rate in both lines was caused by a differential transmission of $0 \mathrm{~B}$ vs. $2 \mathrm{~B}$ gametes and not to a differ- ential ability for $\mathrm{B}$ nondisjunction, because the offspring of $2 \mathrm{~B} \times 0 \mathrm{~B}$ crosses was mainly $2 \mathrm{~B}$ or $0 \mathrm{~B}$ whereas $1 \mathrm{~B}$ plants were hardly found. The present work confirms this result by direct observation of the nondisjunction process at fist pollen anaphase.

We do not know the cause by which the Bs form univalents in a high proportion of the metaphase I cells of the $\mathrm{L}$ line. The available data about synapsis in pachytene studying the synaptonemal complexes in standard rye Bs (Santos et al., 1993) or B derivatives (Jiménez et al., 1994; Santos et al., 1995) show that bivalents are regularly found at pachytene of $2 \mathrm{~B}$ plants. Therefore, it can be suggested that the difference in bivalent vs. univalent formation at metaphase $\mathrm{I}$ in the $\mathrm{L}$ and $\mathrm{H}$ lines is caused by a differential ability for chiasma formation and not to a differential ability for synaptonemal complex formation at pachytene.

In relation to this point it is important to keep in mind that all plants studied in this work carry $2 \mathrm{Bs}$ and come from $2 \mathrm{~B} \times 0 \mathrm{~B}$ crosses; so that the $2 \mathrm{Bs}$ are always produced by nondisjuntion and are identical; therefore, we cannot attribute the lack of chiasmata to differences in homology caused by different origins of the nonpairing Bs.

Besides rye, there is a number of species where 


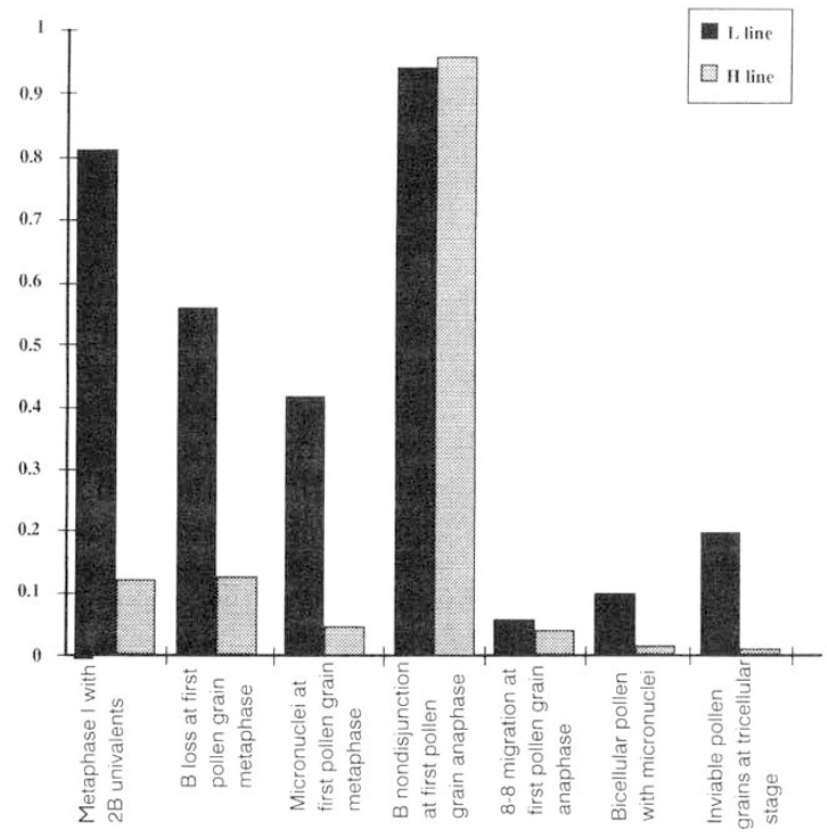

Fig. 1 Comparison of the low and high B transmission rate lines at relevant stages of male meiosis and gametogenesis. The main difference between the two lines is the frequency of cells showing $2 \mathrm{~B}$ univalents vs. 1B bivalent at metaphase I. Many of these univalents are lost as micronuclei which are degraded during pollen maturation. The frequency of nondisjunction in the pollen grains carrying the B is nearly the same in both lines. The frequency of inviable pollen grains is higher in the $\mathrm{L}$ line.

variation in B transmission rates has been reported: Zea mays (Carlson, 1969; Rosato et al., 1996), Hypochoeris maculata (Parker et al., 1982), Myrmeleotettix maculatus (Shaw \& Hewitt, 1985; Shaw et al., 1985), Pseudococcus affinis (Nur \& Brett 1985, 1987, 1988), Crepis capillaris (Parker et al., 1989), Locusta migratoria (Viseras et al., 1990), Nasonia vitripennis (Beukeboom \& Werren, 1993), Aegilops speltoides (Cebriá et al., 1994), Allium schoenoprasum (Bougourd \& Plowman, 1996). In rye, M. maculatus, $P$. affinis, Ae. speltoides and $Z$. mays the genetic control of this variation has been demonstrated and some authors, including ourselves, have taken for granted that this effect is caused by transmissionreducing genotypes of the A chromosomes (Beukeboom, 1994; Jones, 1995 for a review). As a matter of fact this was fully proved only in Nur's studies. The data from the present work do not agree with this hypothesis, at least for the rye lines we have selected. Our data suggest that the lack of chiasmata in the L line may be a feature of the Bs themselves and it is not determined or influenced by the As because the As behave similarly in the $\mathrm{H}$ and $\mathrm{L}$ lines and in cells with $2 \mathrm{~B}$ univalents or $1 \mathrm{~B}$ bivalent.
However, a differential effect of the A genotype on B chromosome meiotic behaviour (synapsis or chiasma formation) cannot be excluded. A study on the localization of the genes controlling B transmission and the coevolutionary forces acting to determine the equilibrium frequencies in populations is necessary for a better understanding of the $B$ polymorphisms.

There is abundant evidence of the parasitic nature of rye Bs maintained by drive despite decreased fitness of B-containing individuals (Jones \& Puertas, 1993 for a review). It was argued, however, (Parker et al., 1982) that if transmission-reducing genotypes existed in populations and could be artificially selected, selection in natural populations could similarly reduce the frequency or eliminate entirely those Bs which reduce overall fitness. The present result that the $\mathrm{L}$ line has a reduced pollen viability whereas in the $\mathrm{H}$ line nearly all pollen grains have a normal appearance is therefore of interest. The long-term benefits of a reduced $B$ transmission seem to be counteracted by the short-term effect of a reduced pollen viability. It is similarly remarkable that when the $\mathrm{B}$ behaviour is regular, according to its own non-Mendelian strategy, pollen grain development is normal.

Rye is the only species where the mechanism of drive acts on both the male and the female sides. The $\mathrm{B}$ transmission rate in the $\mathrm{H}$ and $\mathrm{L}$ lines is different on both sides. In the $\mathrm{L}$ line the mean number of Bs per plant in the progeny is 0.55 when the Bs are transmitted by the female and 1.02 when they are transmitted by the male side, whereas in the $\mathrm{H}$ line these values are 1.85 and 1.31 , respectively. We do not know if these differences are caused by different behaviour of the $\mathrm{B}$ during micro- and megagametogenesis or to competition between $0 \mathrm{~B}$ and B-carrying pollen, or both. We have previously reported differential pollination caused by Bs in rye (Puertas et al., 1986, 1988).

\section{Acknowledgements}

This work was supported by the grant PB 92-0079C03-02 from the DGICYT of Spain.

\section{References}

BEUKEBOOM, L. w. 1994. Bewildering Bs: an impression of the 1st B-chromosome conference. Heredity, 73, 328-336.

BEUKEBOOM, L. W. AND WERREN, J. H. 1993. Transmission and expression of the parasitic paternal sex ratio (PSR) chromosome. Heredity, 70, 437-443.

BOUgourd, S. M. AND PLOWMAN, A. B. 1996. The inherit- 
ance of B chromosomes in Allium schoenoprasum L. Chromosome Res., 4, 151-158.

CARLSON, W. 1969. Factors affecting preferential fertilisation in maize. Genetics, 62, 543-554.

CEbriá, A., NAVARro, M. L. AND pUertas, M. J. 1994. Genetic control of B chromosome transmission in Aegilops speltoides (Poaceae). Am. J. Bot., 81, 1502-1507.

JimÉnEZ, M. M., DíEZ, M. AND SANTOS, J. L. 1994. Synaptic patterns of rye B-chromosomes. III. The deficient B. Chromosome Res., 2, 93-98.

JIMÉNEZ, M. M., ROMERA, F., GALLEGO, A. AND PUERTAS, M. J. 1995. Genetic control of the rate of transmission of rye $\mathrm{B}$ chromosomes. II. $0 \mathrm{~B} \times 2 \mathrm{~B}$ crosses. Heredity, 74 , $518-523$.

JONES, R. N. 1995. Tansley review no. 85. B chromosomes in plants. New. Phytol., 131, 411-434.

JONES, R. N. AND PUERTAS, M. J. 1993. The B chromosomes of rye (Secale cereale L.). In: Dhir, K. K. and Sareen, T. S. (eds) Frontiers in Plant Science Research, pp. 81-112. Bhagwati Enterprises, Delhi.

KISHIKAWA, H. 1965. Cytogenetic studies of B chromosomes in rye, Secale cereale L., in Japan. Agric. Bull. Saga University, 21, 1-81.

MATTHEWS, R. B. AND JONES, R. N. 1982. Dynamics of the B-chromosome polymorphism in rye. I. Simulated populations. Heredity, 48, 345-369.

MATTHEWS, R. B. AND JONES, R. N. 1983. Dynamics of the $B$ chromosome polymorphism in rye II. Estimates of parameters. Heredity, 50, 119-137.

MOGENSEN, H. 1. 1996. The hows and whys of cytoplasmic inheritance in seed plants. Am. J. Bot., 83, 383-404.

NUR, U. AND BRETT, B. L. H. 1985. Genotypes suppressing meiotic drive of a $\mathrm{B}$ chromosome in the mealybug, Pseudococcus obscurus. Genetics, 110, 73-92.

NUR, U. AND BRETT, B. L. H. 1987. Control of meiotic drive of B chromosomes in the mealybug, Pseudococcus affinis (obscurus). Genetics, 115, 499-510.

NUR, U. AND BRETT, B. L. H. 1988. Genotypes affecting the condensation and transmission of heterochromatic $B$ chromosomes in the mealybug Pseudococcus affinis. Chromosoma, 96, 205-212.

PARKER, J. S., TAYLOR, S. AND AINSWORTH, C. C. 1982. The B-chromosome system of Hypochoeris maculata III.
Variation in B-chromosome transmission rates. Chromosoma, 85, 299-310.

PARKER, J. S., JONES, G. H., EDGAR, L. AND WHITEHOUSE, C. 1989. The population cytogenetics of Crepis capillaris. II. The stability and inheritance of B-chromosomes. Heredity, 63, 19-27.

PUERTAS, M. J., DIEZ, M. AND CARMONA, R. 1979. Rye B chromosome behaviour at first and second pollen mitosis and its relationship with anther maturity. Theor. Appl. Genet., 47, 41-43.

PUERTAS, M. J., BAEZA, F. AND DE LA PEÑA, A. 1986. The transmission of $\mathrm{B}$ chromosomes in populations of Secale cereale and Secale vavilovii 1. Offspring obtained from $0 B$ and 2B plants. Heredity, 57, 389-394.

PUERTAS, M. J., JIMÉNEZ, M. M., ROMERA, F., VEGA, J. M. AND DíEZ, M. 1990. Maternal imprinting effect on B chromosome transmission in rye. Heredity, 64, 197-204.

ROMERA, F., JIMÉNEZ, M. M. AND PUERTAS, M. J. 1991. Genetic control of the rate of transmission of rye $B$ chromosomes I. Effects in $2 \mathrm{~B} \times 0 \mathrm{~B}$ crosses. Heredity, 66, 61-65.

Rosato, M., ChIAVARINo, A. M., PUERTAs, M. J., NARANJo, C. A. AND POGGlO, L. 1996. Genetic control of B chromosome transmission in an Argentinian native race of maize. Am. J. Bot., 83, 1107-1112.

SANTOS, J. L., JIMÉNEZ, M. M. AND DíEZ, M. 1993. Synaptic patterns of rye B chromosomes. I. The standard type. Chromosome Res., 1, 145-152.

SANTOS, J. L., JimÉNEZ, M. M. AND DíEZ, M. 1995. Synaptic patterns of rye B chromosomes. IV. The B isochromosomes. Heredity, 74, 100-107.

SHAW, M. W. AND HEWITT, G. M. 1985. The genetic control of meiotic drive acting on the B-chromosome of Myrmeleotettix maculatus (Orthoptera: Acrididae). Heredity, 54, 187-194.

SHAW, M. W., HEWITT, G. M. AND ANDERSON, D. A. 1985. Polymorphism in the rates of meiotic drive acting on the B-chromosome of Myrmeleotettix maculatus. Heredity, 55, 61-68.

VISERAS, E., PARDO, M. C. AND CAMACHO, J. P. M. 1990. Analysis of B chromosome transmission through females of Locusta migratoria. Bull. Genet. Soc. Can., 21 s, 28. 